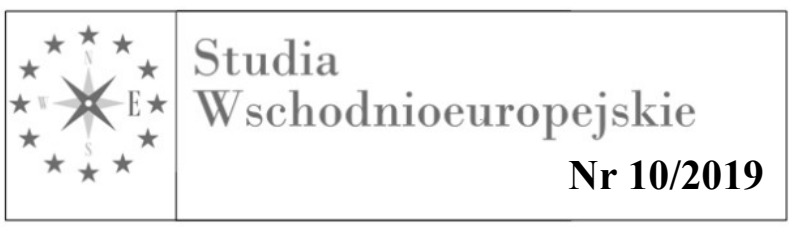

\title{
Przyczyny i skutki migracji zagranicznej z Republiki Mołdawii w latach 1991-2015
}

$\mathrm{M}$ igracja314 jest procesem, który nieodłącznie wiąże się $\mathrm{z}$ dziejami ludzkości. W różnych okresach historycznych, ludzie na skutek kryzysów gospodarczych, konfliktów, łamania praw człowieka, przemocy czy aktów terroru, które zagrażały ich życiu czy dla polepszenia sytuacji materialnej, byli zmuszeni wyjeżdżać do innych bezpiecznych i bogatszych państw.

Szeroka definicja pojęcia migracja, pozwala podzielić ją ze względu na zasięg (wewnętrzna i zewnętrzna - zagraniczna), czas trwania (czasowa i trwała), czynnik decydujący (dobrowolna i przymusowa) oraz powód (ekonomiczny, demograficzny, polityczny, społeczny i religijny).

Sytuacja polityczno-gospodarcza w danym państwie ma znaczący wpływ na proces i skalę migracji jego obywateli. Przykładem państwa, gdzie migracja przybrała charakter masowy jest Republika Mołdawii (Mołdawia). To małe państwo w południowo-wschodniej Europie po rozpadzie ZSRR i odzyskaniu niepodległości, stanęło w obliczu wielu problemów natury politycznej, gospodarczej i społecznej. Problemy okresu transformacji miały wpływ na duży odpływ ludności z tego kraju. Pierwszym etapem była migracja tej części populacji Mołdawian, która ze względu na przynależność narodowościową uzyskała możliwość wyjazdu do kraju pochodzenia. Drugi etap obejmował czasowa migrację handlową i ekonomiczną do państw bardziej rozwiniętymi gospodarczo, jako jeden ze sposobów polepszenia warunków życia w okresie transformacji gospodarczej i politycznej. Trzecim etapem jest długoterminowa migracja, tej części społeczeństwa (w szczególności osób młodych i wykształconych), która wobec braku perspektyw dla poprawy poziomu życia i stabilizacji, spowodowanej pogorszającą się sytuację gospodarczą, zdecydowała się na dłuższy lub stały wyjazd za granicę.

Zjawiskiem pozytywnym tych wyjazdów są przelewy walutowe od mieszkających i pracujących za granicą Mołdawian, które przekazywane do kraju, ratują wiele budżetów domowych i mają znaczący udział w finansach państwa - sięgają średnio 1,3 mld USD rocznie, co stanowi ponad $20 \%$ PKB 315 . Natomiast zjawiskiem negatywnym jest między innymi spadek populacji oraz „drenaż mózgów”, tzn. wyjazdy wykształconej części społeczeństwa posiadającej wysokie kwalifikacje zawodowe i ludzi młodych - głównie studentów.

\section{Przyczyny migracji zagranicznej Mołdawian}

Republika Mołdawii jest państwem liczącym ponad 4 miliony mieszkańców (wliczają w to około pół miliona mieszkańców Naddniestrza), położonym pomiędzy Rumunią a Ukrainą. Odzyskanie niepodległości w 1991 roku w wyniku rozpadu Związku Radzieckiego, dla tego małego kraju Europy Wschodniej otworzyło wiele możliwości rozwoju, ale także

314 A. Runge, J. Runge, Migracja ludności-zmiana miejsca zamieszkania lub czasowego pobytu, Stownik pojęć z geografii społeczno-ekonomicznej, Chorzów 2008, s. 200.

315 National Bureau of Statistics of the Republic of Moldova, Moldova in Figurs Statistical pocket-book, za: http://statistica.gov.md/public/files/publicatii_electronice/Moldova_in_cifre/2018/Breviar_en_2018.pdf (22.09.2019), s. 63 . 
zaktualizowało wiele problemów. Nowo utworzony aparat państwowy, musiał zapewnić rozwój demokratycznego systemu politycznego, przestrzeganie prawi wolności człowieka oraz zwiększyć poziom rozwoju gospodarczego.

Wraz z odzyskaniem suwerenności nastąpił głęboki kryzys ekonomiczny, który wiązał się ze zmianą gospodarki centralnie planowanej na gospodarkę rynkową i procesów związanych $\mathrm{z}$ transformacją ustrojową. Gospodarka radzieckiej Mołdawii była wyspecjalizowana $\mathrm{w}$ dostarczaniu żywności do pozostałych republik. Związku Socjalistycznych Republik Radzieckich (ZSRR), a wraz z jego upadkiem przyszło załamanie gospodarki mołdawskiej. Kolejny cios padł ze strony Naddniestrza, które w 1990 roku ogłosiło niepodległość. Na terenie tej separatystycznej republiki znajdowała się połowa mołdawskiego przemysłu i wszystkie elektrownie.

Skutki kryzysu - wysoka inflacja, bezrobocie spowodowane likwidacją większości przedsiębiorstw przemysłowych i rolno-przemysłowych - zmusiły większość ludzi do życia na granicy ubóstwa. W tym okresie wiele mniejszości narodowych Mołdawii wyjechało do krajów swojego pochodzenia. Cześć tych osób, mając możliwość otrzymania obywatelstwa Rosji czy Ukrainy, decydowała się na zamieszkanie w tych krajach na stałe.

Na przestrzeni 25 lat od odzyskania niepodległości, działania kolejnych rządów nie doprowadziły do stworzenia stabilnego rozwoju gospodarki mołdawskiej. W konsekwencji Mołdawia nadal pozostała jednym z najbiedniejszych krajów Europy, z gospodarką funkcjonującą na niskoprzetworzonych produktach rolno-spożywczych, gdzie aż $30 \%$ mieszkańców kraju pracuje w sektorze rolnym. Państwo to nie posiadając własnych bogatych złóż surowców energetycznych jest całkowicie uzależnione od importu zewnętrznego, przede wszystkim z Rosji a to wiąże się z podatnością na wpływy politycznogospodarcze Kremla. Dużym problemem dla Mołdawii są kwestie związane $\mathrm{z}$ korupcją $\mathrm{w}$ administracji państwowej i nieprzejrzystym systemem bankowo-finansowym, przykładem tego negatywnego zjawiska była afera bankowa z 2014 r. i wyprowadzenie z państwowego systemu bankowego ok. 1 mld USD316.

Mołdawia jest krajem o najbardziej dynamicznych procesach migracyjnych w całej przestrzeni postradzieckiej. Od momentu zmiany systemu politycznego i załamania się gospodarki kraju, Mołdawia została dotknięta masową migracją zarobkową, która objęła 40\% osób w wieku produkcyjnym317. Na początku okresu transformacji, z uwagi na brak barier wizowych i językowych, najczęściej wybieranym kierunkiem poszukiwania pracy była Federacja Rosyjska (głównie Moskwa i inne duże miasta). Większość wyjeżdżających osób do pracy za granicę stanowili fizyczni pracownicy sezonowi. Wśród najczęściej wymienianych motywów migracji zarobkowej był brak środków finansowych na podstawowe utrzymanie, opłacenie nauki, sfinansowania kupna mieszkania bądź spłatę długu.

Zjawisko migracji zagranicznej, wpłynęło bardzo niekorzystnie na problemy demograficzne kraju, w latach 1990-2015 liczba ludności Mołdawii (z uwzględnieniem Naddniestrza) zmniejszyła się o ponad 300 tysięcy osób. W 1990 roku było 4359377 obywateli a w 2015 roku 4030859 obywateli (z tym Mołdawia 3555159 a Naddniestrze 475 700) 318.

\footnotetext{
${ }^{316}$ K. Całus, Państwo niedokończone 25 lat mołdawskiej niepodległości, Warszawa 2016, nr 59, s. 27

317 International Labour Organization, Migrant Workers: The Case of Moldova, Geneva 2017, za: https://www.ilo.org/wcmsp5/groups/public/ed_protect/protrav/migrant/documents/publication/wcms_613508 (22.09.2019).

318 Narodowe Biuro Statyczne Republiki Mołdawii (dane z 1990 r. $\quad$ i 2015 r.), za: http://statbank.statistica.md/pxweb/pxweb/ro/20\%20Populatia\%20si\%20procesele\%20demografice/20\%20Popul atia\%20si\%20procesele\%20demografice_POP_POP010/POP010100.px/table/tableViewLayout1/?rxid=9a62a 0d7-86c4-45da-b7e4-fecc26003802 (22.09.2019); porównaj także А. Кривенко, Молдова: страна массовой трудовой эмиграции, za: http://demoscope.ru/weekly/2014/0605/analit05.php (22.09.2019); dane statystyczne dotyczące Naddniestrza, International Organization for Migration Mission in Moldavia (The UN Migration
} 
Według danych Mołdawskiego Instytutu Polityki Publicznej, w 2015 roku niezadowolenie $\mathrm{z}$ sytuacji gospodarczej $\mathrm{w}$ kraju deklarowało 92\% obywateli. $\mathrm{Z}$ poziomu płac i z sytuacji na rynku pracy, niezadowolonych było $96 \%$ pracujących a z wysokości emerytur $94 \%$ - ponieważ wynagrodzenie za pracę czy emerytury nie były adekwatne do cen artykułów konsumpcyjnych 319. Średnia mołdawska pensja w 2015 roku wynosiła nieco ponad 4,6 tys. lei (ok. 200 euro) i była najniższa w całej Europie 320. A średnia emerytura wynosiła w Mołdawii zaledwie 1100 lei (ok. 50 euro) 321.

Niska wydajność sektora przetwórczego powodowała, że chociaż Mołdawia jest krajem głównie rolniczym, to większość przetworzonych produktów żywnościowych musi importować, a to przekłada się na wysokie ceny towarów. Ponad 37\% Mołdawian w 2015 roku deklarowało, że ich dochody nie wystarczają nawet na pokrycie podstawowych potrzeb, a kolejne $41,4 \%$ - że środków starcza im tylko na niezbędne wydatki322.

W przeprowadzonych przez United Nations Development Programme (program ds. rozwoju) - agendę Organizacji Narodów Zjednoczonych (ONZ), badaniach współczynnika rozwoju społecznego (współczynnik Human Development Index (HDI), Mołdawia od początku swojej niepodległości utrzymuje mniej więcej ten sam wynik punktowy $(0,652 \mathrm{w} 1990$ roku wobec $0,693 \mathrm{w}$ roku 2015), oznacza to brak zauważalnej poprawy poziomu życia mieszkańców. W rezultacie, o ile w roku 1990 kraj ten plasował się na 61. miejscu rankingu HDI, o tyle w roku 2015 znalazł się na miejscu 107. (w bezpośrednim sąsiedztwie Egiptu, Botswany i Turkmenistanu). Dla porównania z innymi krajami postradzieckimi to w 2015 roku Białoruś uplasowała się na 50 miejscu, Gruzja na 76 a Ukraina na 81323.

Potwierdziły to również badania opinii publicznej, z których wynikało, że obywatele pozbawieni są nadziei na poprawę sytuacji materialnej. Aż 69\% Mołdawian w 2015 roku deklarowało, że nie widzi poprawy sytuacji gospodarczej w ciągu najbliższych kilku lat lub też oczekuje jej pogorszenia. Winą za fatalną sytuację społeczno-gospodarczą ankietowani obwiniali władzę i wskazywali na powszechną korupcję w kraju324.

Do migracji Mołdawian przyczyniła się także prowadzona przez Rumunię od 1991 roku polityka nadawania (przywracania) obywatelstwa. Objęła ona byłych obywateli rumuńskich (i ich potomków), którzy utracili obywatelstwo na skutek zmian terytorialnych po II wojnie światowej. Adresowana była ona do mieszkańców tych terenów, które przed 1940 rokiem należały do Rumunii, a więc Mołdawii (bez Naddniestrza) oraz leżących obecnie w granicach Ukrainy północnej Bukowiny i Budziaku. Działania władz rumuńskich, podyktowane były naprawieniem przymusowego pozbawienia obywatelstwa rumuńskiego mieszkańców anektowanej po 1945 roku przez ZSRR Besarabii. W rezultacie tej polityki od roku 199 do 2013 liczba Mołdawian posiadających paszporty rumuńskie wynosiła około 400_

Agency), Extended Migration Profile of Transnistria, December 2017, za: https://www.iom.md/sites/default/files/publications/docs/Extended\%20Migration\%20Profile\%20of\%20Transnist ria.pdf (22.09.2019).

319 Institutul de Politici Publice, Barometrul de Opinie Publică Aprilie 2016, za: http://www.ipp.md/public/files/Barometru/BOP_04.2016_prima_parte_finale-r.pdf(25.09.2019), s. 56.

$320 \quad$ Narodowe $\quad$ Biuro Statystyczne $\quad \bar{R}$ Republiki $\quad$ Mołdawii, http://statbank.statistica.md/pxweb/pxweb/en/30\%20Statistica $\% 20$ sociala/30\%20Statistica\%20sociala_03\%20F M_SAL010_serii\%20lunare/SAL014800.px/table/tableViewLayout1/?rxid=f8b627b8-6246-4f1 f-a89cf7 $\overline{5 \mathrm{a}} 45015 \mathrm{a} 2 \overline{\mathrm{e}}(25.09 .2019)$.

$321 \quad$ Narodowe Biuro Statystyczne Republiki Mołdawii, http://statbank.statistica.md/pxweb/pxweb/en/30\%20Statistica\%20sociala/30\%20Statistica\%20sociala_09\%20P RO/PRO011700reg.px/table/tableViewLayout1/?rxid=e3583fe1-0364-40f1-a109-824499f892f9 (25.09.2019).

322 Institutul de Politici Publice, Barometrul de Opinie ..., op. cit., s.78.

323 Human Development Indices and Indicators 2018 Statistical Update, Briefing note for countries on the 2018 Statistical Update Moldova, za: http://hdr.undp.org/sites/all/themes/hdr_theme/country-notes/MDA.pdf (26.09.2019).

324 Ibidem, s. 79 . 
500 tysięcy. Co ważne, regulacje związane z przywracaniem obywatelstwa rumuńskiego nie wymagały od Mołdawian ani zrzeczenia się posiadanego obywatelstwa, ani też przeprowadzki do Rumunii. Dzięki temu mołdawscy posiadacze paszportów rumuńskich na równi $\mathrm{z}$ Rumunami mogą bez trudu podejmować legalną pracę na terenie całej Unii Europejskiej (UE) 325 .

Na kwestie migracyjne wpływ mają także relacje polityczne i ekonomiczne z Rosją oraz kwestia Naddniestrza (enklawy na wschodzie Mołdawii). Rosja podejmuje wobec Mołdawii szereg działań o charakterze politycznym, wojskowym i gospodarczym. Do nich należy między innymi: wojna informacyjna, polityka wręczania paszportów mieszkańcom Naddniestrza (60\% stanowią Rosjanie i Ukraińcy), wspieranie konfliktu w Naddniestrzu oraz ograniczanie dostaw surowców energetycznych czy zakazy importu mołdawskich towarów.

\section{Pozytywne i negatywne skutki migracji zagranicznej}

Problemy $\mathrm{z}$ migracją nie ominęły żadnej $\mathrm{z}$ byłych republik postradzieckich, a Mołdawia zajmuje wśród nich czołowe miejsce. Polityczne i gospodarcze konsekwencje transformacji a także późniejsze globalne kryzysy ekonomiczne miały decydujący wpływ na procesy migracyjne.

Brak stabilności politycznej i problemy gospodarcze w Mołdawii spowodowały, że jej obywatele oraz częściej zaczęli wybierać ścieżkę czasowej migracji zarobkowej lub ostatecznie zdecydowali się na stałe opuszczenie kraju326.

W okresie istnienia ZSRR polityka migracyjna państwa była regulowana w bardzo rygorystyczny sposób. Dotyczyło to w szczególności wewnętrznych przepływów migracyjnych ze wsi do miast. Wymóg posiadania wewnętrznego paszportu (dowodu osobistego) z poświadczonym zameldowaniem na danym terenie oraz posiadanie odrębnego zezwolenia na pobyt poza miejscem zameldowania, skutecznie utrudniał obywatelom swobodę przemieszczania się. W rzeczywistości oznaczało niemożność korzystania z części własnych praw osobistych, na przykład prawa do swobodnej zmiany miejsca pracy, prawa do edukacji, a w niektórych przypadkach nawet prawa swobodnego podróżowania po kraju. Warto zauważyć, że prawo do przeniesienia się i zameldowani w mieście było ściśle reglamentowane i kontrolowane przez władze. Powodem tego było między innymi niedopuszczenie do wyludniania się obszarów wiejskich. Poziom kontroli zależał od znaczenia miasta, najbardziej rygorystyczną kontrolę przeprowadzono w stolicach republik ZSRR i dużych miastach. Mieszkańcy wsi, postrzegani przez władze jako podstawa systemu społecznego, mieli swobodę przemieszczania się, ale tylko po obszarach wiejskich327. Przepisy dotyczące rejestracji pobytu, a także systemu pozwoleń wyjazdowych, zostały zniesione dopiero w $1990 \mathrm{r}$.

Po 1991 roku do migracji wewnętrznej, dochodziło najczęściej z powodu spadku poziomu rozwoju i możliwości generowania dochodów z rolnictwa. Dodatkowym czynnikiem zjawiska migracji był gwałtowny wzrost poziomu urbanizacji i życia w mieście. Proces taki przebiegał według schematu ze wsi do miasta a później $\mathrm{z}$ miasta do stolicy w Kiszyniowie. Jednocześnie warto zauważyć, że przyczyniło się to do wytworzenia swoistego

325 Szerzej o kwestii nadawania obywatelstwa rumuńskiego, K. Całus, W cieniu historii. Stosunki RumuńskoMołdawskie, Warszawa 2015, nr 53, s. 27-30.

326 А.В. Макухин, Современная миграционная ситуация в республике Молдова населения, который и При днестроаье как череёа «исхоаоа» населения, „Politbook”, Москва 2015, nr 1, s. 71.

327 Постановление Совета Министров СССР от 28 августа 1974 г. 677 „Об утверждении положения о паспортной системе в СССР“, za: http://dokipedia.ru/document/5288587 ( 27.09 .2019 ). 
kompleksu podwójnej tożsamości migrujących osób i do zaostrzenia odwiecznego konfliktu między kulturą miejską a wiejską.

Natomiast pierwsze przejawy migracji zagranicznej w Mołdawii, miały miejsce na fali „pierestrojki” pod koniec lat 80-tych XX wieku. Proces ten był jednak mały i dotyczył głównie diaspory żydowskiej jako grupy wyznaniowej mieszkające na terytorium ZSRR, która otrzymała prawo wyjazdu do Izraela, Stanów Zjednoczonych i Kanady. Szacuje się, że repatriacja Mołdawian narodowości żydowskiej objęła pomiędzy 30-45 tys. osób328.

Wraz $z$ rozpadem Związku Radzieckiego i odzyskaniem niepodległości, Mołdawia stanęła w obliczu poważnych problemów narodowościowych. Nowy kurs polityczny pierwszego niekomunistycznego rządu w Kiszyniowie, był wyraźnie zorientowany na zjednoczenie $\mathrm{z}$ sąsiednią Rumunią. $\mathrm{Z}$ wielu powodów było to nie do przyjęcia dla większości przedstawicieli mniejszości narodowych, co ostatecznie doprowadziło do serii starć zbrojnych i podziału terytorialnego kraju (powstanie Naddniestrzańskiej Republiki Mołdawskiej). Konflikt naddniestrzański doprowadził do migracji etnicznych Rosjan, Ukraińców i Żydów, obawiających się o własne bezpieczeństwo. Konflikt ten spowodował, że w latach 1993-1997 najwięcej wyjazdów miało miejsce do Izraela, Stanów Zjednoczonych i Niemiec oraz państw postradzieckich: Ukrainy, Rosji i częściowo Białorusi329.

W Mołdawii, kraju pozbawionym zasobów naturalnych oraz zaplecza przemysłowego, od roku 1995 zaczęła pojawiać stale rosnąca tendencja do masowej zagranicznej migracji zarobkowej zarówno legalnej jak i nielegalnej. Głównym motywem wzrostu tego zjawiska było brak stabilności politycznej i stale pogarszająca się sytuacja gospodarcza. Dodatkowym, a zarazem nieoczekiwanym ciosem dla mołdawskiej gospodarki, był kryzys gospodarczy w Rosji w 1998 r., która w tym czasie była najważniejszym partnerem gospodarczym Mołdawiiz30.

Z danych opracowanych przez Ministerstwo Spraw Zagranicznych (MSZ) Republiki Mołdawii, wynika, że od 1991 roku do 2015 roku aż 15-20\% populacji (około 800 tys. osób) 331 wyjechało w poszukiwaniu lepszego życia i pracy za granicą. W praktyce oznacza to, że w tym okresie ubyło około 40 \% Mołdawian zdolnych do pracy332.

Na podstawie raportu o migracji zagranicznej, opracowanego przez Ministerstwo Spraw Zagranicznych Republiki Mołdawii oraz Międzynarodową Organizację do Spraw Migracji (IOM) za lata 2010-2015 wynika, że w 2015 roku Federacja Rosyjska znajdowała się na szczycie zestawienia państw do których w poszukiwaniu pracy, najczęściej legalnie wyjeżdżali Mołdawianie (w proc.) 333:

- 2015 rok: Federacja Rosyjska 42 \%; Ukraina 13,7 \%; USA 12,6\%; Niemcy 11,1\%; Izrael $7,6 \%$, inne państwa $10,1 \%$.

328 И. Сафонов, Евреи в Молдове - 500 лет вместе, Панорама 15.04.2011, zа: https://press.try.md/item.php?id=119758 (30.09.2019).

329 О. М. Поалелунжь, Молдова в потоке международной миграчии, [в:] Основные вызовы демографической безопасности: сходства и различия в Молдове и Беларуси, Кишинев 2010, s. 156.

330 В. Мошняга, Население Молдовы в контексте современных миграчионных проов, Молдова. Приднестровье: Работая вместе ради успешного будущего, Киев 2009, s. 156.

331 Zgodnie z danymi mołdawskiego MSZ za granicą przebywało (stan na 31 grudnia 2015 roku) ok. 805 tysięcy obywateli mołdawskich, szacuje się, że mnie więcej połowę tej grupy stanowią migranci sezonowi, za: http://www.noi.md/md/news_id/89997 (30.09.2019).

332 Wyliczenia własne na podstawie danych Narodowego Biura Statystycznego Republiki Mołdawii: „Structura populaţiei stabile a Republicii Moldova pe sexe şi vîrste la 1 ianuarie 2016", http://www.statistica.md/newsview.php?l=ro\&idc=168\&id=5210 (30.09.2019).

333 International Organization for Migration Mission in Moldavia (The UN Migration Agency), Extended Migration Profile of the Republic of Moldova 2010-2015 Analytical Report, Overview of Migration Trends for the Period 2005-2015, Chisinau 2017, za: https://iom.md/sites/default/files/publications/docs/Extended\%20Migration\%20Profile\%20of\%20the\%20Republ ic\%20of\%20Moldova\%202010-2015.pdf (1.10.2019), s. 14. 
- dla porównania w 2010 rok: Federacja Rosyjska 28 \%; Ukraina 43,3 \%; USA 13,5\%; Niemcy 4,6\%; Izrael 4,9\%, inne państwa 1,9\%,

Natomiast $\mathrm{z}$ danych opracowanych przez placówki dyplomatyczne i konsularne Republiki Mołdawii - za lata 2011-2015 wynika, że szacunkowa liczba obywateli tego kraju, przebywających za granicą (niezależnie od długości pobytu w kraju docelowym) 334 przedstawia się następująco:

- w 2011 roku - 505139 osób,

- w 2012 roku - 755983 osób,

- w 2013 roku - 819542 osób,

- w 2014 roku - 983708 osób (od 2014 roku obowiązuje ruch bezwizowy z państwami UE na pobyt nie dłuższy niż $90 \mathrm{dni}$ ),

- w 2015 roku - 805509 osób, w tym między innymi:

- Federacja Rosyjska 477 949,

- Włochy 142 266,

- Kanada 17 565,

- Ukraina 17 237,

- Hiszpania 16202 ,

- Niemcy 14815 ,

- Izrael 13 005,

- Rumunia 9277.

Z danych raportu o migracji zagranicznej, opracowanego przez MSZ Republiki Mołdawii oraz Międzynarodową Organizację do Spraw Migracji (IOM) w latach 2010-2015, można wyodrębnić liczbę obywateli, którzy wyjechali z Mołdawii na stałe335:

- w 2010 roku - 92184 osób,

- w 2011 roku - 96223 osób,

- w 2012 roku - 99352 osób,

- w 2013 roku - 101937 osób,

- w 2014 roku - 104311 osób,

- w 2015 roku - 106595 osób, w tym między innymi:

- Federacja Rosyjska 35 101,

- Ukraina 29 756,

- USA 29 756,

- Niemcy 12 165,

- Izrael 7642.

Masowa migracja zagraniczna, jaka ma miejsce w Mołdawii ma pozytywne i negatywne skutki społeczno-gospodarcze.

Do pozytywnych skutków można zaliczyć przelewy walutowe od migrantów zarobkowych, które korzystnie wpływają na poziom życia ich rodzin w kraju i wzrost mołdawskiego PKB.

W latach 1999 - 2015 wartość przekazów pieniężnych od osób przebywających za granicą wynosiła (w milionach dolarów amerykańskich) 336:

$$
\begin{aligned}
& \text { - 1999 - 89,62 USD } \\
& \text { - 2000 - 152,94 USD } \\
& \text { - 2003 - 317,76 USD } \\
& \text { - 2006 - 854,55 USD } \\
& \text { - 2008 - 1 612,12 USD }
\end{aligned}
$$

334 Ibidem, s. 117.

335 Ibidem, s. 115.

336 Traasferuri din strainatate efectuate in favoarea persoanelor fizice. Banca Nationala a Moldovei, za: https:// www.bnm.md/md/external_operations_via_banc_system (1.10.2019). 
- 2010 - 1244,14 USD

- 2012 - 1 494,23 USD

- $2014-1612,96$ USD

- 2015 - 1 129,12 USD

Zagraniczne wpływy pieniężne miały swoje znaczące przełożenie na mołdawski PKB, ich udział procentowy w latach $1999-2015$ wynosił337:

- $1999-9,3 \%$

$-2000-12,3 \%$

$-2003-23,5 \%$

$-2006-38,2 \%$

$-2008-30,8 \%$

$-2010-29,9 \%$

$-2012-23,9 \%$

$-2014-27,8 \%$

$-2015-23,1 \%$.

Pieniądze otrzymywane $\mathrm{z}$ zagranicy zamiast iść na inwestycje i rozwój kraju, są niemal $\mathrm{W}$ całości wykorzystywane na bieżącą konsumpcję. W rezultacie przelewy od migrantów zarobkowych, choć stymulują konsumpcję wewnętrzną i wpływają pozytywnie na poziom życia $\mathrm{w}$ kraju, to nie tworzą fundamentów dla stabilnego rozwoju gospodarczego Mołdawii. Tymczasem liczne grono mołdawskich migrantów długoterminowych, potrafiło $w$ ciągu ostatnich dwóch dekad założyć za granicą (głównie na terenie UE) dobrze prosperujące firmy i zgromadziło wiedzę, kapitał oraz doświadczenie do prowadzenia biznesu.

Rząd w Kiszyniowie, przy odpowiednich zachętach podatkowych i korzystnych warunkach prawno-administracyjnych mógłby ten kapitał i to doświadczenie umiejętnie wykorzystać. Przyczyniłoby się to nie tylko do rozwoju gospodarczego Mołdawii i zmniejszenia bezrobocia, ale także sprzyjałoby przenoszeniu na mołdawski grunt zachodnich standardów biznesowych. Wydaje się, że skuteczną metodą skłaniania migrantów do inwestowania we własnym kraju jest podniesienie konkurencyjności tamtejszej gospodarki, połączone $\mathrm{z}$ jej liberalizacją $\mathrm{i}$ depolityzacją oraz radykalne ograniczenie korupcji w administracji państwowej także radykalna reforma sądownictwa. Bez realnych działań w tych obszarach, szanse na zainteresowanie mołdawskich migrantów inwestowaniem w ojczyźnie wydają się bardzo niewielkie.

Natomiast negatywnymi konsekwencjami procesu migracyjnego są przede wszystkim problemy demograficzne (wyludnianie się kraju) a przy tym osłabienie potencjału ludzkiego $\mathrm{z}$ powodu wyjazdu najbardziej wykształconych i aktywnych zawodowo osób. Ogranicza to liczbę osób zdolnych do podjęcia pracy na rynku lokalnym, co pozbawia Mołdawię jednego z podstawowych fundamentów rozwoju gospodarczego.

Dodatkowo migracja stworzyła problem tzw. sierot emigracyjnych (dzieci pozostawionych w kraju pod opieką dalszej rodziny, których rodzice zmuszeni zostali do podjęcia pracy za granicą). Wzrost liczby pozostawionych dzieci, przyczynia się to do osłabienia więzów rodzinnych i rozpadu rodzin.

Innym istotnym negatywnym zjawiskiem migracji dla gospodarki mołdawskiej jest tzw. drenaż mózgów, związany z odpływem z kraju osób najlepiej wykształconych i doświadczonych. Problem ten dotyczy dwóch kategorii społecznych: wysoko wykwalifikowanych specjalistów (lekarzy, techników, informatyków i innych) oraz ludzi młodych - w tym studentów. Masowa skala wyjazdów ograniczyła możliwości rozwoju nowoczesnych gałęzi gospodarki i wpływa bardzo negatywnie na działanie niektórych 
sektorów publicznych, szczególnie służby zdrowia. Od momentu uzyskania niepodległości około 40\% mołdawskich lekarzy $\mathrm{w}$ tym kraju zrezygnowało $\mathrm{z}$ pracy i w większości wyjechało za granicę. Odpływ specjalistów, połączony z utrzymującym się niedofinansowaniem służby zdrowia sprawia, że Mołdawia musi dziś mierzyć się z takimi problemami, jak wzrost wskaźnika umieralności.

Drugą kategorią migrujących są studenci. W 2015 roku około $20 \%$ z nich studiowało na zagranicznych uczelniach. Zdecydowana większość studentów z tej grupy (ok. 90\%) kształciła się na uczelniach rumuńskich, co wynika z jednej strony z kulturowej i językowej bliskości Mołdawian i Rumunów, a $z$ drugiej - z rozbudowanych programów stypendialnych oferowanych przez Bukareszt młodym Mołdawianom. Zdecydowana większość uczących się za granicą Mołdawian wobec perspektywy niskich zarobków w kraju oraz niskiej jakości życia decyduje się na pozostanie po studiach za granicą338.

Mołdawskie władze zupełnie nie radzą sobie $\mathrm{z}$ ograniczaniem zjawiska migracji. W zachęcaniu migrantów do powrotu nie pomaga słaba tożsamość narodowa i brak przywiązania do państwa mołdawskiego. Wydaje się przy tym, że władze w Kiszyniowie postrzegają migrację jako zjawisko $\mathrm{z}$ ich punktu widzenia korzystne. Pozwala ono bowiem rozładować w pewnym stopniu napięcia społeczne wywołane złą sytuacją gospodarczą, ograniczyć bezrobocie oraz zasilić budżety rodzinne, co wpływa korzystnie na konsumpcję wewnętrzną. Jednocześnie do wyjazdów zarobkowych skłaniają się przede wszystkim ludzie młodzi i aktywni, choć jest to zjawisko negatywne społecznie - dodatkowo ogranicza ryzyko poważnych antyrządowych wystąpień czy przewrotów.

\section{Umowa stowarzyszeniowa z UE}

Od 2009 roku Mołdawia jest beneficjentem unijnego programu Partnerstwa Wschodniego339, kolejnym krokiem było podpisanie w 2014 roku umowy stowarzyszeniowej z UE340. Umowa stowarzyszeniowa nakreśliła program reform $\mathrm{w}$ wielu obszarach, jedną z nich są kwestie związane z migracją. Na podstawie podpisanej umowy, obywatele Mołdawii mogą na okres nie dłuższy niż 90 dni wyjeżdżać do państw UE bez wiz, ale tylko na podstawie paszportów biometrycznych.

Według danych mołdawskiej służby granicznej w okresie roku od prowadzenia ruchu bezwizowego (od 28 kwietnia 2014 roku do 27 kwietnia 2015 roku) do państw UE wyjechało ponad 241 tys. Mołdawian. Wbrew prognozom, zniesienie wiz nie spowodowało znacznego wzrostu wyjazdów Mołdawian do UE ani też zwiększenia liczby wniosków o status uchodźcy składanych w krajach unijnych.

Niewątpliwą korzyścią dla społeczeństwa mołdawskiego z wprowadzenia ruchu bezwizowego jest swoboda podróżowania do UE. Jednocześnie nie zmniejszyło to w sposób wyraźny zainteresowania Mołdawian możliwością otrzymania rumuńskiego obywatelstwa (obecnie ma go ok. 500 tys. Mołdawian), które daje także możliwość uzyskania legalnego zatrudnienia w państwach UE. Oznacza to, że wyjazdy do państw UE, szacowane na ok. 300 tys. osób, realizowane są w sposób racjonalny i przemyślany, zaś migranci poszukują przede wszystkim legalnej możliwości osiedlenia i zatrudnienia w UE, a nie zaś możliwości samego wjazdu.

Zniesienie wiz przez UE spowodowało wzrost zainteresowania mieszkańców Naddniestrza uzyskaniem mołdawskich paszportów. Wprowadzenie ruchu bezwizowego do UE w obu

\footnotetext{
338 K. Całus, Państwo niedokończone ....,, op. cit., s. 60-61.

339 Wspólna deklaracja szczytu Partnerstwa Wschodniego w Pradze (7 maja 2009), za: https://www.consilium.europa.eu/media/31797/2009_eap_declaration.pdf, (1.10.2019).

340 Układ o Stowarzyszeniu między Unią Europejską i Europejską Wspólnotą Energii Atomowej oraz ich państwami członkowskimi, z jednej strony, a Republiką Mołdawii, z drugiej strony, Dz. Urz. EU L 260/4 z 27.06.2014.
} 
częściach Mołdawii pokazało, że może on funkcjonować w przypadku podzielonych państw, bez większych wyzwań dla bezpieczeństwa regionu. Niestety ułatwienia podróżowania do UE nie stały się zachętą dla rządu Mołdawii, aby kontynuować proces reform gospodarczych, a nastąpiło wręcz ich zahamowanie341.

\section{Wnioski}

Od momentu odzyskania niepodległości w 1991 roku, skala migracji w Republice Mołdawii osiągnęła bardzo poważne rozmiary. Skala procesów migracyjnych jest charakterystyczna dla tych krajów, które przeszły ustrojową i gospodarczą transformację. Ma to swoje konsekwencje w wielu sferach funkcjonowania społeczeństwa i państwa.

Migracja zarobkowa pozostaje najbardziej rozpowszechnioną formą wyjazdów z Mołdawii w poszukiwaniu lepszego życia i pracy, a jej główne kierunki to Rosja, Ukraina oraz państwa UE. Podstawowym motywem stymulującym do wyjazdu są niskie zarobki i emerytury, brak perspektyw stabilizacji czy chęć poprawienia poziomu życia.

Migracje są procesem o sprzecznych konsekwencjach. Z jednej strony przyczyniają się do bogacenia się państwa, dzięki przekazom walutowym mołdawskich migrantów zagranicznych (w 2015 roku stanowiły one 23\% PKB Mołdawii). A z drugiej strony powodują problemy demograficzne i osłabianie potencjału państwa ze względu na wyjazdy osób w wieku produkcyjnym, szczególnie tych przedsiębiorczych i najlepiej wykształconych 342.

Uzależnienie gospodarki Mołdawii od transferów pieniężnych przesyłanych z zagranicy przez mieszkających i pracujących tam Mołdawian oznacza, że każda zmiana ustawodawstwa dotyczącego migrantów w krajach UE lub Rosji, może przełożyć się na ograniczenie możliwości migracji, a w konsekwencji może doprowadzić do poważnego kryzysu gospodarczego w Mołdawii. Negatywną konsekwencją migracji jest także „drenaż mózgów". Najlepiej wykształceni ludzie, w tym lekarze czy inżynierowie, decydują się wyjechać, widząc za granicą znacznie lepsze możliwości rozwoju oraz warunków życia i pracy. Zjawisko migracji dotyczy także ludzi młodych, co ma szczególne konsekwencje społeczne w Mołdawii, bo zachwiana została równowaga pokoleniowa i przesunęła się na korzyść najstarszej części społeczeństwa.

Procesy migracyjne jakie miały miejsce w Mołdawii pomiędzy 1991 a 2015 rokiem pokazują wyraźnie, że pomimo upływu lat państwo to nadal ma problemy natury politycznej i gospodarczej. Do nich możemy zaliczyć, brak kontroli nad całym terytorium i znacznej części granicy, brak skutecznej i odpowiedzialnej klasy politycznej, nie funkcjonuje efektywny system polityczny i ekonomiczny. Brakuje spójnej i akceptowalnej idei rozwoju i stabilnej gospodarki. Utrzymywanie się tych problemów sprawia, że Mołdawia nie tylko nie jest $\mathrm{w}$ stanie skutecznie realizować wielu podstawowych zadań leżących tradycyjnie w kompetencji państwa (szczególnie w zakresie społecznym czy instytucjonalnym), a co ważne, pozostaje wciąż państwem pozbawionym wizji rozwoju.

Rząd w Kiszyniowie poprzez swoją politykę społeczną i gospodarczą a także dzięki współpracy z UE, powinien starać się zwrócić większą uwagę na problemy migracji własnych obywateli. Widać wyraźnie, że największym wyzwaniem dla Mołdawii jest groźba depopulacji - wyludnianie się Mołdawii, w dłuższej perspektywie może to doprowadzić do zapaści systemu emerytalnego i finansów publicznych.

341 M. Jarosiewicz, K. Całus, Mołdawia: rok po wprowadzeniu ruchu bezwizowego, Analizy OSW, 06.05.2015, za: https://www.osw.waw.pl/pl/publikacje/analizy/2015-05-06/moldawia-rok-po-wprowadzeniu-ruchubezwizowego (1.10.2019).

342 W. Konończuk, Pomiędzy Unią Europejska a Rosją. Problematyka migracji z Białorusi, Ukrainy i Mołdawii, Warszawa 2005, s. 1-2. 


\section{Streszczenie}

Celem artykułu jest przedstawienie przyczyn i skutków migracji zagranicznej obywateli Mołdawii jakie miały miejsce w latach 1991 - 2015. W wyniku przemian politycznych, kryzysów gospodarczych, wewnętrznych konfliktów i nierozstrzygniętego statusu quasipaństwa Naddniestrza, migracja zagraniczna w Mołdawii przybrała charakter masowy i stanowi najpoważniejszy problem państwa. Przypadek ten będzie zilustrowany poprzez analizę przyczyn i skutków migracji $\mathrm{w}$ aspekcie pozytywnym i negatywnym, na podstawie danych statystycznych i artykułów naukowych dotyczących problemów migracyjnych. Celem poznawczym będzie przedstawienie skali migracji do roku 2015 oraz czynników wpływających na proces migracji obywateli tego wschodnioeuropejskiego państwa. Artykuł będzie próbą poszukiwania odpowiedzi na pytanie, o zagrożenia jakie niesie ze sobą migracja oraz czy Mołdawia jest w stanie powstrzymać ten proces poprzez reformy społeczno-gospodarcze i integrację z Unią Europejską.

\section{Słowa kluczowe:}

Mołdawia, migracja, społeczeństwo, gospodarka, Naddniestrze

\section{Keywords:}

Moldova, migration, socjety, economy, Transnistria

\section{Bibliografia:}

1. Сафонов И., Евреи в МолДове - 500 лет вместе, Панорама 15.04.2011, zа: https://press.try.md/item.php?id=119758 (30.09.2019).

2. Całus K., Państwo niedokończone 25 lat mołdawskiej niepodległości, Warszawa 2016, nr 59.

3. Całus K., W cieniu historii. Stosunki Rumuńsko-Mołdawskie, Warszawa 2015, nr 53.

4. Human Development Indices and Indicators 2018 Statistical Update, Briefing note for countries on the 2018 Statistical Update Moldova, za: http://hdr.undp.org/sites/all/themes/hdr_theme/country-notes/MDA.pdf (26.09.2019).

5. Institutul de Politici Publice, Barometrul de Opinie Publică Aprilie 2016, za: http://www.ipp.md/public/files/Barometru/BOP_04.2016_prima_parte_finale-r.pdf (25.09.2019).

6. International Labour Organization, Migrant Workers: The Case of Moldova, Geneva 2017 ,

https://www.ilo.org/wcmsp5/groups/public/ed_protect/protrav/migrant/documents/pub lication/wcms_613508.pdf.

7. International Organization for Migration Mission in Moldavia (The UN Migration Agency), Extended Migration Profile of the Republic of Moldova 2010-2015 Analytical Report, Overview of Migration Trends for the Period 2005-2015, Chisinau 2017, za: https://iom.md/sites/default/files/publications/docs/Extended\%20Migration\%20Profile \%20of\%20the\%20Republic\%20of\%20Moldova\%202010-2015.pdf (1.10.2019). 
8. International Organization for Migration Mission in Moldavia (The UN Migration Agency), Extended Migration Profile of Transnistria, December 2017, za: https://www.iom.md/sites/default/files/publications/docs/Extended\%20Migration\%20 Profile\%20of\%20Transnistria.pdf (22.09.2019).

9. Jarosiewicz M., Całus K., Mołdawia: rok po wprowadzeniu ruchu bezwizowego, Analizy OSW 06.05.2015, za: https://www.osw.waw.pl/pl/publikacje/analizy/2015-0506/moldawia-rok-po-wprowadzeniu-ruchu-bezwizowego (1.10.2019).

10. Konończuk W., Pomiędzy Unia Europejska a Rosją. Problematyka migracji z Białorusi, Ukrainy i Mołdawii, Warszawa 2005.

11. Кривенко А., Молдова: страна массовой трудовой эмиграции, za: http://demoscope.ru/weekly/2014/0605/analit05.php (22.09.2019).

12. Макухин А.В., Современная миграџионная ситуаџия в республике Молдова населения, который и Приднестроаье как череёа «исхоаоа» населения, „Politbook“, nr 1, Москва 2015.

13. Ministerstwo Spraw Zagranicznych Republiki Mołdawii, http://www.noi.md/md/news_id/89997 (30.09.2019).

14. Мошняга В., Население Молдовы в контексте современных миграционных проов, Модова - Приднестровье: Работая вместе ради успешного будущего, Киев 2009.

15. National Bureau of Statistics of the Republic of Moldova, Moldova in Figurs Statistical pocketbook, http://statistica.gov.md/public/files/publicatii_electronice/Moldova_in_cifre/2018/Bre viar_en_2018.pdf (30.09.2019).

16. Narodowe Biuro Statyczne Republiki Mołdawii, za: http://statbank.statistica.md/pxweb/pxweb/ro/20\%20Populatia\%20si\%20procesele $\% 2$ 0demografice $/ 20 \% 20$ Populatia $\% 20 \mathrm{si} \% 20$ procesele $\% 20$ demografice_POP_POP010/ POP010100.px/table/tableViewLayout1/?rxid=9a62a0d7-86c4-45da-b7e4fecc26003802 (22.09.2019).

17. Narodowe Biuro Statystyczne Republiki Mołdawii, za: http://statbank.statistica.md/pxweb/pxweb/en/30\%20Statistica\%20sociala/30\%20Stati stica\%20sociala_03\%20FM_SAL010_serii\%20lunare/SAL014800.px/table/tableV iewLayout1/?rxid=f8b627b8-6246-4f1f-a $89 \mathrm{c}-\mathrm{f} 75 \mathrm{a} 45015 \mathrm{a} 2 \mathrm{e}(25.09 .2019)$.

18. Narodowe Biuro Statystyczne Republiki Mołdawii, za: http://statbank.statistica.md/pxweb/pxweb/en/30\%20Statistica\%20sociala/30\%20Stati stica\%20sociala_09\%20PRO/PRO011700reg.px/table/tableViewLayout1/?rxid=e358 3 fe1-0364-40f1-a109-824499f892f9 (25.09.2019).

19. Narodowe Biuro Statystyczne Republiki Mołdawii, Structura populatiei stabile a Republicii Moldova pe sexe şi vîrste la 1 ianuarie 2016, http://www.statistica.md/newsview.php?l=ro\&idc=168\&id=5210 (30.09.2019).

20. Поалелунжь О. М., Молдова в потоке международной миграции, [в:] Основные вызовы демографической безопасности: сходства и различия в Молдове и Беларуси, Кишинев 2010.

21. Постановление Совета Министров СССР от 28 августа 1974 г. 677 „Об утверждении положения о паспортной системе в СCCP“, za: http://dokipedia.ru/document/5288587 (27.09.2019). 
22. Runge A., Runge J., Słownik pojęć z geografii społeczno-ekonomicznej, Chorzów 2008.

23. Wspólna deklaracja szczytu Partnerstwa Wschodniego w Pradze (7 maja 2009), za: https://www.consilium.europa.eu/media/31797/2009_eap_declaration.pdf (1.10.2019).

24. Układ o Stowarzyszeniu między Unią Europejską i Europejską Wspólnotą Energii Atomowej oraz ich państwami członkowskimi, z jednej strony, a Republiką Mołdawii, z drugiej strony, Dz. Urz. EU L 260/4 z 27.06.2014. 